\title{
RISK MANAGEMENT IN ORGANIC FERTILIZER SUPPLY CHAIN ACTIVITIES
}

\section{Irine Octaviani, Djoko Koestiono, Anisa Aprilia}

\author{
Departement of Socio Economics, Faculty of Agriculture, Brawijaya University, Jl. Veteran, Malang \\ 65145 , Indonesia \\ Email: anisa.asa@ub.ac.id
}

Diterima 25 Juni 2019 , disetujui 5 Mei 2020

\begin{abstract}
Supply chain management is not easy because there are two challenges that must be faced, namely, the complexity of the supply chain structure and the uncertainty that occurs suddenly, therefore these conditions are vulnerable to various forms of risk. The research was conducted by the aim of identify the risks, causes of risk and determining the right strategy to deal with the causes of risk in supply chain activities at PT. MBA. House of Risk (HOR) was used by five indicators in the SCOR (Supply Chain Operation Reference) model, consists of plan, source, manufacture, distribution and return. Risk events were identified and considered priorities, namely delays in receiving raw materials from suppliers, implementation of production not on schedule, no production process activities, unable to meet all demands, decreasing product quality during the process, product quality not in accordance with existing standards and delays product delivery (finished good) to PT. PKG. The priority risk agent is a risk agent to check inaccurate raw materials. Meanwhile, the handling strategy that is a priority to be implemented, with the hope of being able to prevent the causes of risk is coordination, stock strategy and flexible supply base.
\end{abstract}

Keywords: supply chain, house of risk, risk management strategy

\section{INTRODUCTION}

Companies in running a business are required to have the right strategy to survive in business competition. The strategy that can be conducted is to manage the supply chain appropriately (Tampubolon et al., 2013). According to Pujawan (2005) and Punniyamoorthy et al., (2013), factors that cause risk in the supply chain include increasingly complex supply chain networks, high dependence on suppliers and differences in organizational interactions in the supply chain. If the risks to the supply chain are not immediately addressed, disruption to the supply chain has the potential to be very dangerous and expensive, resulting in low service levels and high costs (Blackhurst \& Handfield, 2005).
Anatan \& Ellitan (2008) and Pujawan (2005) states that the complexity of the supply chain structure is due to the involvement of many parties inside and outside the company, each of which has different interests and often conflicts between one and the other. The challenge that must be faced in managing the supply chain in addition to the complexity of the supply chain structure is uncertainty. Uncertainty in the supply chain can be classified into 3 , that is demand uncertainty, supplier uncertainty and internal uncertainty.

PT. MBA is one company that produces organic fertilizer, under PT. PKG. PT. MBA is required to increase productivity in every process of production, both in terms of increasing production yields, quality and quantity of production and efficient use of 
resources. Uncertainty in raw materials with company demands, lack of coordination between PT. MBA with raw material suppliers and a high dependence on suppliers creates a risky occurrence. In addition, business activities at PT. MBA involve various actors, ranging from procurement of raw materials, flow of raw materials from suppliers to factories and then processed and then distributed. The chain of activities is defined as a supply chain. Meanwhile, supply chain is a series of activities that cover the process of transformation and distribution of goods, ranging from raw materials to finished products to end consumers (Anwar, 2011).

The level of dependence and complexity in the supply chain causes the overall supply chain to be more susceptible to disruptions. Disruptions that occur in one supply chain actor can affect the supply chain as a whole, such as the flow of information and resource from upstream to downstream (Suharjito et al., 2010). According to Kersten et al., (2007), supply chain risk is the possibility of damage caused by an event or action from supply chain actors and their environment that causes a negative influence on business processes in the supply chain network.

The emergence of risk in supply chain activities must be estimated and handled thus it is not to interfere with company objectives. Therefore, companies need to manage supply chain risk at PT. MBA than so that the company can survive and continue efforts to achieve profits. Supply Chain Risk Management (SCRM) deals with the risks that occur in the flow of products, information and raw materials for the delivery of the final product (Juttner et al., 2003). There are four elements in supply chain risk management, namely risk identification, risk assessment, risk mitigation and responses to risk incidents stemming from operational risks derived from supply and demand uncertainty and disaster risk (Tang \& Nurmaya Musa, 2011).

Based on the background of this research, the purposes of the research were identify the causes of risk in supply chain activities and determine the right strategies to deal with the causes of risk in the supply chain activities at PT. MBA. The scope of this research were focus on supply chain activities at PT MBA. Thus, it was expected that this research can provide advice and recommendations for companies in managing and resolving the risks that occur and can help PT. MBA to deal with the risks that arise in the supply chain, reduce or even eliminate events and causes of risk in the supply chain. Thus, PT MBA can compete with other organic fertilizer companies, increase and / or stabilize organic fertilizer production.

\section{RESEARCH METHODS}

The method of determining the location of the research was conducted purposively at PT. MBA with consideration, that is: (1) PT. MBA is one of the companies that produce organic fertilizer and partnered with PT. PKG. Given that PT. The MBA is one company that produces agricultural inputs that are always needed to meet the demand for organic fertilizer to be subsidized by the government, meanwhile in companies that produce organic fertilizer such as PT. MBA, organic fertilizer supply chain activities have the opportunity to arise risks. (2) PT. The MBA has not applied risk management in the organic fertilizer supply chain, (3) research has never been conducted in relation to risk analysis in supply chain activities at PT. MBA, (4) Positive company response in research on risk analysis in the supply chain.

The method of determining informants was conducted by purposive sampling technique with the type of judgment sampling. Informants were production and logistics managers of PT. MBA and determined based on the consideration that the production and logistics manager of PT. MBA was aware of supply chain activities, thus they can identify risks for supply chain activities. The method used in data collection was interviews, conducted to determine the company's supply chain activities and to identify risks that occur in the company's 
supply chain activities and the causes of risk. Data collection methods with documentation were used to obtain secondary data in the form of general company data which includes company history and data flow of raw material procurement, and distribution.

Data analysis method used in this study was the House of Risk (HOR) method developed by Pujawan and Geraldin (2009). The House of Risk (HOR) method was a method that focuses on preventive actions, that is reducing the possible causes of risk (Pujawan \& Geraldin, 2009).

According to Pujawan (2005), the application of the SCOR (Supply Chain Operation Reference) model is one of the supply chain operating models used to measure supply chain performance based on the process. The SCOR model integrates three main elements in management, that is business process reengineering, benchmarking and measuring processes into a cross-functional framework in the supply chain. Based on research conducted by Astutik et al (2010); Luthfi \& Irawan (2012); Tampubolon et al., (2013); Kristanto \& Hariastuti (2014); Ulfah \& Syamsul (2016); Citraresmi (2017); Ummi et al., (2017); Immawan \& Putri (2018), the SCOR model can be used to analyze risks in supply chain activities without initiating a supply chain performance analysis of the three elements.

According to Pujawan \& Geraldin (2009) and Tampubolon et al., (2013) the application of the HOR method has two stages:

A. House of Risk 1 (HOR 1)

HOR 1 was used to identify risks and causes of risk events thus from HOR 1, the cause of prioritized risks can be generated to take precautions in accordance with ARP values. The HOR 1 process has several stages of work:

1) Identifying risk events that can occur in each business process. This was conducted through the supply chain mapping process of the SCOR model including (plan, source, make, deliver and return) and then identify what is missing / wrong in each process.

2) Assess the severity if a risk event occurs, using a scale of $1-5$ where 5 is very severe.

3) Identification of the causes of risk and the value of possible causes of risk using a 1-5 scale where 1 means that almost never occurs and a value of 5 means often.

4) Develop matrix relationships. The relationship between each cause of risk and each risk event, $\mathrm{Rij}(0,1,3,9)$ where 0 shows no correlation and 1, 3, 9 show the low, medium and high correlations respectively.

5) Calculates the ARPj value as in equation (1).

$$
\mathrm{ARP}_{\mathrm{j}}=\mathrm{O}_{\mathrm{j}} \sum \mathrm{S}_{\mathrm{i}} \mathrm{R}_{\mathrm{i} j}
$$

6) The rating of the causes of risk was based on the potential risk from the biggest value to the lowest value.

B. House of Risk 2 (HOR 2)

HOR 2 was used to design strategies to deal with the causes of priority category risks. Action strategies were carried out by considering the involvement of resources and the level of difficulty in the implementation. The output from HOR 1 will be used as input for HOR 2. The application of HOR 2 includes several stages of work:

1) Choose the cause of risk starting from the highest to lowest ARP values that might use a pareto diagram.

2) Identify actions that was considered relevant (PAk) to prevent the cause of risk. It should be noted that one cause of risk can be handled with more than one action and one action simultaneously can reduce the likelihood of more than one cause of risk.

3) Determine the relationship between each precautionary measure and each cause of risk, Ejk. Its value $(0,1,3,9)$ which shows no consecutive, low, medium and high relationships between actions $\mathrm{k}$ and causes of risk j. The relationship (Ejk) will be a consideration in determining the degree of effectiveness of the action $\mathrm{k}$ in reducing the likelihood of risk-causing events.

4) Calculate the total effectiveness (TEk) of each action, using the following calculation:

$$
\mathrm{Te}_{\mathrm{k}}=\sum_{\mathrm{j}} \mathrm{ARP}_{\mathrm{j}} \mathrm{E}_{\mathrm{jk}}
$$


5) Assess the level of difficulty in the application of action handling, Dk. The level of difficulty can be represented by the level of difficulty scale. The scale consists of $(3,4$ and 5) which shows that the strategy is easily realized, strategies are difficult to realize and strategies are difficult to realize.

6) Calculate the effectiveness of the total difficulty ratio:

$$
\mathrm{ETD}_{\mathrm{k}}=\frac{\mathrm{Tek}}{\mathrm{Dk}}
$$

7) Determining the priority ranking for each action (Rk) was the first rank that gives the highest meaning of action with ETDk.

\section{RESULTS AND DISCUSSIONS}

\section{Structure of Organic Fertilizer Supply Chain}

PT. MBA only works with one supplier for each raw material. Risk management in the organic fertilizer supply chain activities in this study only covers the upstream supply chain and internal supply chain. The role of each party involved in the organic fertilizer supply chain at PT. MBA as follows:

1.Suppliers: PT. MBA only works with one supplier for each raw material, that is chicken manure collectors, cow manure collectors, while blotong is supplied directly from Sugar Factory (PG).

2.PT. MBA: has a role as a processor in the organic fertilizer supply chain and does not have the power to market its production fertilizer.

3.PT. PKG: Organic Fertilizer from PT. MBA will be sent to PT. PKG. The warehouse in the organic fertilizer supply chain serves to connect PT. PKG with distributors.

\section{Mapping Supply Chain Activities}

Supply chain activity mapping is the initial stage in the House of Risk (HOR) method, mapping activities based on SCOR, namely plan, source, make, deliver / distribution and return (Pujawan \& Geraldin, 2009). Mapping supply chain activities at PT. MBA based on the SCOR model as in Table 1, as follows:

Table 1. Mapping of Supply Chain Activities at PT. MBA Based on SCOR Model

\begin{tabular}{|c|c|}
\hline $\begin{array}{l}\text { Major Processes/ } \\
\text { Concept of SCOR }\end{array}$ & $\begin{array}{c}\text { Sub Processes/ } \\
\text { Activities of PT. MBA }\end{array}$ \\
\hline \multirow{4}{*}{ Plan } & Forecasting the demand for organic fertilizer from PT. PKG \\
\hline & Organic fertilizer production planning \\
\hline & Production capacity planning \\
\hline & Raw material planning \\
\hline \multirow{3}{*}{ Source } & Receive of raw material delivery \\
\hline & Checking of raw material delivery \\
\hline & Authorizing payment of raw materials sent by suppliers \\
\hline \multirow{4}{*}{ Make } & Production scheduling \\
\hline & Production processes \\
\hline & Checking of product quality \\
\hline & Packaging process \\
\hline \multirow{3}{*}{ Delivery } & Delivery selection \\
\hline & Warehouse of finished products \\
\hline & Shipping goods / products \\
\hline \multirow{2}{*}{ Return } & Handling of defect products from PT. PKG \\
\hline & Handling delivery of new products to PT. PKG \\
\hline
\end{tabular}

Source: primary data processed (2018) 


\section{Identify Risk Events in Supply Chain Activities}

Risk event identification was carried out to determine the risks that occur and the risks that have the potential to occur in supply chain activities of the company PT. MBA. Identification of risk events for each business process that has been identified was an event that may arise / arise and cause disruption of supply chain activities that result in company losses (Geraldin et al., 2007); (Luthfi \& Irawan, 2012); (Tampubolon et al., 2013); (Ulfah \& Syamsul, 2016). The following were risk events in supply chain activities at PT. MBA.

Based on the results of the analysis in table 2 there were 23 risk events identified in all stages of the organic fertilizer supply chain activity process at $\mathrm{PT}$. MBA using the SCOR model which consists of five business processes (plan, source, make, deliver and return). Risk events that have been identified in the supply chain activities of PT. The MBA is in the activity plan there are 5 risk events. In the source activity there are 3 risk events. In the make activity there are 6 risk events. On deliver activities there are 6 risk events. In return activity there are 2 risk events

Identification of Risk Causes in Supply Chain Activities

The risk agent identification was carried out to find out what factors cause the occurrence of the risk events that have been identified. Risk agents are things that can cause a risk event to occur thus it can disrupt the company's supply chain activities

Table 2. Identification of Risk Events Based on Supply Chain Activities in PT. MBA

\begin{tabular}{|c|c|c|c|c|}
\hline $\begin{array}{c}\text { Major } \\
\text { Processes }\end{array}$ & Sub Processes & Risk Event & $\begin{array}{l}\text { Cod } \\
\text { e }\end{array}$ & $\begin{array}{l}\text { Severity } \\
\text { Value }\end{array}$ \\
\hline \multirow{5}{*}{ Plan } & $\begin{array}{l}\text { Forecasting the } \\
\text { demand for } \\
\text { organic fertilizer } \\
\text { from PT. PKG }\end{array}$ & $\begin{array}{l}\text { Determine the inappropriate amount } \\
\text { of demand for organic fertilizer from } \\
\text { PT. PKG (error forecasting) }\end{array}$ & E1 & 2 \\
\hline & \multirow[t]{2}{*}{$\begin{array}{l}\text { Raw material } \\
\text { planning }\end{array}$} & $\begin{array}{l}\text { The gap between the recorded stock } \\
\text { and available stock (incompatibility } \\
\text { between total capacity and existing } \\
\text { conditions) }\end{array}$ & E2 & 2 \\
\hline & & Inaccurate inventory parameters & E3 & 1 \\
\hline & $\begin{array}{l}\text { Planning for } \\
\text { organic fertilizer } \\
\text { production }\end{array}$ & $\begin{array}{l}\text { Errors / changes in plans for } \\
\text { production of sudden organic } \\
\text { fertilizer }\end{array}$ & E4 & 3 \\
\hline & $\begin{array}{l}\text { Production } \\
\text { capacity planning }\end{array}$ & $\begin{array}{l}\text { Capacity planning is not conducted } \\
\text { as planned }\end{array}$ & E5 & 2 \\
\hline \multirow{3}{*}{ Source } & $\begin{array}{l}\text { Acceptance of raw } \\
\text { material delivery }\end{array}$ & $\begin{array}{l}\text { Delays in receiving raw materials } \\
\text { from suppliers }\end{array}$ & E6 & 4 \\
\hline & $\begin{array}{l}\text { Checking raw } \\
\text { material shipments }\end{array}$ & $\begin{array}{l}\text { Errors in raw materials received } \\
\text { from suppliers (the quality received } \\
\text { is not suitable and the amount of raw } \\
\text { material received is not in } \\
\text { accordance with the order) }\end{array}$ & E7 & 3 \\
\hline & $\begin{array}{l}\text { Provision of } \\
\text { payment } \\
\text { authorization for } \\
\text { raw materials sent } \\
\text { by suppliers }\end{array}$ & $\begin{array}{l}\text { Error in authorizing payment of raw } \\
\text { materials sent by suppliers }\end{array}$ & E8 & 1 \\
\hline
\end{tabular}




\begin{tabular}{|c|c|c|c|c|}
\hline \multirow[t]{7}{*}{ Make } & $\begin{array}{l}\text { Production } \\
\text { scheduling }\end{array}$ & $\begin{array}{l}\text { Delay in production schedule / } \\
\text { production implementation is not on } \\
\text { schedule }\end{array}$ & E9 & 4 \\
\hline & $\begin{array}{l}\text { Production } \\
\text { implementation }\end{array}$ & $\begin{array}{l}\text { There are no production process } \\
\text { activities }\end{array}$ & E10 & 4 \\
\hline & & $\begin{array}{l}\text { Not able to meet all demands / } \\
\text { production unable to meet demand } \\
\text { (incompatibility production capacity } \\
\text { by the number of products to be } \\
\text { produced) }\end{array}$ & E11 & 4 \\
\hline & $\begin{array}{l}\text { Product quality } \\
\text { check Quality }\end{array}$ & $\begin{array}{l}\text { The decline in quality throughout } \\
\text { the process }\end{array}$ & E12 & 4 \\
\hline & & $\begin{array}{l}\text { The quality of the product does not } \\
\text { comply with existing standards }\end{array}$ & E13 & 4 \\
\hline & Packaging process & Leakage of product packaging & E14 & 1 \\
\hline & & Dirty packaging & E15 & 1 \\
\hline \multirow[t]{6}{*}{$\begin{array}{l}\text { Deliver } \\
\text { or } \\
\text { Distribution } \\
\end{array}$} & Selection delivery & $\begin{array}{l}\text { Data incompatibility of product } \\
\text { number on the system with existing } \\
\text { conditions }\end{array}$ & E16 & 1 \\
\hline & $\begin{array}{l}\text { Warehouse of } \\
\text { finished good }\end{array}$ & The product is not handled & E17 & 2 \\
\hline & Delivery of goods/ & $\begin{array}{l}\text { Delay in the delivery of organic } \\
\text { fertilizer products to PT. PKG }\end{array}$ & E18 & 4 \\
\hline & & $\begin{array}{l}\text { Error (in quantity) of product } \\
\text { delivery to PT. PKG }\end{array}$ & E19 & 2 \\
\hline & & $\begin{array}{l}\text { Products sent to the wrong } \\
\text { destination }\end{array}$ & E20 & 2 \\
\hline & & Product damage during the trip & E21 & 2 \\
\hline \multirow[t]{2}{*}{ Return } & $\begin{array}{l}\text { Handling of defect } \\
\text { products from PT. } \\
\text { PKG }\end{array}$ & $\begin{array}{l}\text { Late in handling organic fertilizer } \\
\text { returns from PT. PKG }\end{array}$ & E22 & 3 \\
\hline & $\begin{array}{l}\text { Handling the } \\
\text { delivery of defect } \\
\text { products to PT. } \\
\text { PKG }\end{array}$ & $\begin{array}{l}\text { Delay in the delivery of defect } \\
\text { products to industry users of PT. } \\
\text { PKG }\end{array}$ & E23 & 3 \\
\hline
\end{tabular}

(Geraldin et al., 2007); (Tampubolon et al., 2013). According to Pujawan \& Geraldin (2009) a risk agent can induce more than one risk event and the presence of a risk event cannot be separated from the accompanying risk agent (Luthfi \& Irawan, 2012).

Based on Table 3, it can be seen that there are 35 risk agents that have the potential to trigger risk events in supply chain activities of PT. MBA.

\section{Assessment of the Relationship Level between Risk Events and Risk Agents}

According to Ulfah \& Syamsul (2016), a risk cause causes a risk event, so there is a correlation. The higher the correlation shows the greater correlation between the incidence of risk and the cause of risk. Aggregate Risk Potentials (ARP) are used to determine the priority of risk agents that need to be handled / designed by the strategy (Geraldin et al., 2007); (Luthfi \& Irawan, 2012); (Pujawan \& Geraldin, 2009); (Ulfah \& 
Syamsul, 2016).

Based on Table 4, it was obtained information that the highest ARP value has a value of 495 which indicates that the risk agent has the highest priority for handling compared to other risk agents. Risk agent that has the highest value is A21, a risk agent code for checking raw materials that are not accurate.

According to Luthfi \& Irawan (2012) the higher the ARP value of a risk agent will be directly proportional to the level of impact

Table 3. Assessment Risk Agent

\begin{tabular}{|c|c|c|c|}
\hline No. & Code & Risk Agent & $\begin{array}{l}\text { Occurrence } \\
\text { Value }\end{array}$ \\
\hline 1. & A1 & Significant increase in demand for organic fertilizer. & 2 \\
\hline 2. & $\mathrm{~A} 2$ & Seasonal factors. & 2 \\
\hline 3. & A3 & Lack of information and communication. & 2 \\
\hline 4. & A4 & Sudden demand of organic fertilizer & 2 \\
\hline 5. & A5 & Raw material inventory data is not immediately in up to date. & 3 \\
\hline 6. & A6 & Sudden raw material / material demand. & 4 \\
\hline 7. & A7 & Delays in the procurement of raw materials. & 5 \\
\hline 8. & A8 & The ability of suppliers to meet demand on schedule is low. & 5 \\
\hline 9. & A9 & Poor coordination in the warehouse of raw material storage. & 4 \\
\hline 10. & A10 & Incorrect price reference. & 1 \\
\hline 11. & A11 & Lack of raw materials supply in warehouses. & 2 \\
\hline 12. & A12 & The occurrence of trouble / damage to the engine. & 2 \\
\hline 13. & A13 & Factor reliability of machine tools during the process. & 1 \\
\hline 14. & A14 & Power supply is interrupted. & 1 \\
\hline 15. & A 15 & Coal supply is disrupted. & 1 \\
\hline 16. & A16 & Shut down production. & 2 \\
\hline 17. & A17 & Demand for sudden purchase of raw materials. & 4 \\
\hline 18. & A18 & Interference with raw materials during the trip. & 4 \\
\hline 19. & A19 & Depends on one supplier. & 5 \\
\hline 20. & A 20 & List of raw material purchases is not clearly specified. & 4 \\
\hline 21. & $\mathrm{~A} 21$ & Checking the quality of raw materials that are not accurate. & 5 \\
\hline 22. & $\mathrm{~A} 22$ & Lack of maintenance management. & 1 \\
\hline 23. & A23 & Unused raw materials. & 1 \\
\hline 24. & $\mathrm{~A} 24$ & Error in sampling. & 2 \\
\hline 25. & A25 & $\begin{array}{l}\text { The occurrence of packaging contamination during the storage } \\
\text { process. }\end{array}$ & 2 \\
\hline 26. & A26 & Checking the quality of the final product that is not accurate & 2 \\
\hline 27. & A 27 & Error input data of finished products (organic fertilizer) & 1 \\
\hline 28. & A 28 & $\begin{array}{l}\text { Data on the results of finished products are not immediately up } \\
\text { to date }\end{array}$ & 1 \\
\hline 29. & A29 & Limited warehouse area of production. & 4 \\
\hline 30. & $\mathrm{~A} 30$ & Limited transportation. & 1 \\
\hline 31. & A 31 & Transport equipment is damaged. & 1 \\
\hline 32. & A32 & Lack coordination in shipping. & 2 \\
\hline 33. & A33 & Natural disasters. & 1 \\
\hline 34. & A34 & Disturbance during the product delivery. & 4 \\
\hline 35. & A35 & $\begin{array}{l}\text { Transportation means that are not safe from environmental } \\
\text { factors. }\end{array}$ & 1 \\
\hline
\end{tabular}

Source: primary data processed (2018) 
that will be caused in the company's supply chain activities. However, Luthfi \& Irawan
(2012) also mentioned that not all risk agents get a handling, it is caused by several factors,

Table 4. Risk Agent

\begin{tabular}{|c|c|c|c|c|c|c|}
\hline No. & Risk Agent & ARP & Rank & $\begin{array}{c}\text { Cumulative } \\
\text { ARP }\end{array}$ & $\%$ ARP & $\begin{array}{c}\% \\
\text { Cumulative ARP }\end{array}$ \\
\hline 1. & A21 & 495 & 1 & 495 & $16.47 \%$ & $16.47 \%$ \\
\hline 2. & A7 & 395 & 2 & 890 & $13.14 \%$ & $29.62 \%$ \\
\hline 3. & A19 & 315 & 3 & 1205 & $10.48 \%$ & $40,10 \%$ \\
\hline 4. & A12 & 246 & 4 & 1451 & $8.19 \%$ & $48.29 \%$ \\
\hline 5. & A16 & 158 & 5 & 1609 & $5.26 \%$ & $53.54 \%$ \\
\hline 6. & A17 & 144 & 6 & 1753 & $4.79 \%$ & $58.34 \%$ \\
\hline 7. & A1 & 132 & 7 & 1885 & $4.39 \%$ & $62.73 \%$ \\
\hline 8. & A4 & 102 & 8 & 1987 & $3.39 \%$ & $66.12 \%$ \\
\hline 9. & A15 & 111 & 9 & 2098 & $3.69 \%$ & $69.82 \%$ \\
\hline 10. & $\mathrm{~A} 32$ & 96 & 10 & 2194 & $3.19 \%$ & $73.01 \%$ \\
\hline 11. & A9 & 92 & 11 & 2286 & $3.06 \%$ & $76.07 \%$ \\
\hline 12. & A34 & 92 & 12 & 2378 & $3.06 \%$ & $79.13 \%$ \\
\hline 13. & A14 & 88 & 13 & 2466 & $2.93 \%$ & $82.06 \%$ \\
\hline 14. & A5 & 54 & 14 & 2520 & $1,80 \%$ & $83.86 \%$ \\
\hline 15. & A11 & 54 & 15 & 2574 & $1.80 \%$ & $85.66 \%$ \\
\hline 16. & $\mathrm{~A} 2$ & 38 & 16 & 2612 & $1.26 \%$ & $86.92 \%$ \\
\hline 17. & A20 & 36 & 17 & 2648 & $1.20 \%$ & $88.12 \%$ \\
\hline 18. & A26 & 36 & 18 & 2684 & $1.20 \%$ & $89.32 \%$ \\
\hline 19. & A13 & 33 & 19 & 2717 & $1.10 \%$ & $90.42 \%$ \\
\hline 20 & A8 & 30 & 20 & 2747 & $1.00 \%$ & $91.41 \%$ \\
\hline 21. & A31 & 30 & 21 & 2777 & $1.00 \%$ & $92.41 \%$ \\
\hline 22. & A3 & 24 & 22 & 2801 & $0.80 \%$ & $93.21 \%$ \\
\hline 23. & A6 & 24 & 23 & 2825 & $0.80 \%$ & $94.01 \%$ \\
\hline 24. & A22 & 24 & 24 & 2849 & $0.80 \%$ & $94.81 \%$ \\
\hline 25. & A24 & 24 & 25 & 2873 & $0.80 \%$ & $95.61 \%$ \\
\hline 26. & A29 & 24 & 26 & 2897 & $0.80 \%$ & $96.41 \%$ \\
\hline 27. & A30 & 21 & 27 & 2918 & $0.70 \%$ & $97.10 \%$ \\
\hline 28. & A33 & 21 & 28 & 2939 & $0.70 \%$ & $97,80 \%$ \\
\hline 29. & A18 & 16 & 29 & 2955 & $0.53 \%$ & $98.34 \%$ \\
\hline 30. & $\mathrm{~A} 25$ & 12 & 30 & 2967 & $0.40 \%$ & $98.74 \%$ \\
\hline 31. & A35 & 11 & 31 & 2978 & $0.37 \%$ & $99.10 \%$ \\
\hline 32. & A27 & 9 & 32 & 2987 & $0.30 \%$ & $99.40 \%$ \\
\hline 33. & A28 & 9 & 33 & 2996 & $0.30 \%$ & $99.70 \%$ \\
\hline 34. & A23 & 8 & 34 & 3004 & $0.27 \%$ & $99.97 \%$ \\
\hline 35. & A10 & 1 & 35 & 3005 & $0.03 \%$ & $100.00 \%$ \\
\hline
\end{tabular}

Source: primary data processed (2018) 
that is in terms of the costs incurred in the handling process and the level of impact caused is considered too small. The results of calculating the ARP value were then ranked using the Pareto diagram shown in Figure 1.

Determination of the priority risk agent category was conducted by using the pareto principle $80: 20$. The principle states that $80 \%$ of the company's losses were caused by $20 \%$ of crucial risk agents, meaning that by focusing $20 \%$ of the risk agents that were crucial, the impact of the company's risk or $80 \%$ risk event can be overcome (Luthfi \& Irawan, 2012); (Pujawan \& Geraldin, 2009).

Based on Table 4 and Figure 1 it can be seen that with the Pareto 80:20 principle, 12 risk agents were obtained from 35 risk agents which were the cause of the risk of supply chain activities at PT. MBA and made into consideration in the preparation of risk management strategies.

\section{Risk Management Strategy}

Based on Figure 4, there were 12 risk agent priorities that were used as consideration in the preparation of risk management strategies. According to Pujawan \& Geraldin (2009) one risk agent can be handled with more than one action and one action simultaneously can reduce the possibility of more than one risk agent. A plan of handling strategies to be carried out to deal with the risk agent can be seen in Table 5 .

Risks cannot be avoided but can be minimized by handling appropriate risks so as to minimize costs, time and performance in supply chain activities (Handayani, 2016). Assessment of risk management strategies was based on the level of difficulty in each strategy (Nurlela \& Suprapto, 2014).

Based on the value of ETD (Effectiveness to Difficulty) contained in the number 6 risk management strategies that have the highest value, namely coordination (PA5) with a value of 3943 . Those strategy was used to handle several risk agents and can be applied easily in terms of costs and resources.

The value of effectiveness to difficulty showed that the level of effectiveness of the strategy after consideration of the ability to be applied to a business entity. The higher the value of effectiveness to difficulty, the strategy is increasingly a priority to be applied. The risk management strategy that has the lowest ETD (Effectiveness to Difficulty) value was flexible transportation (PA9) with a value of 69. The following was

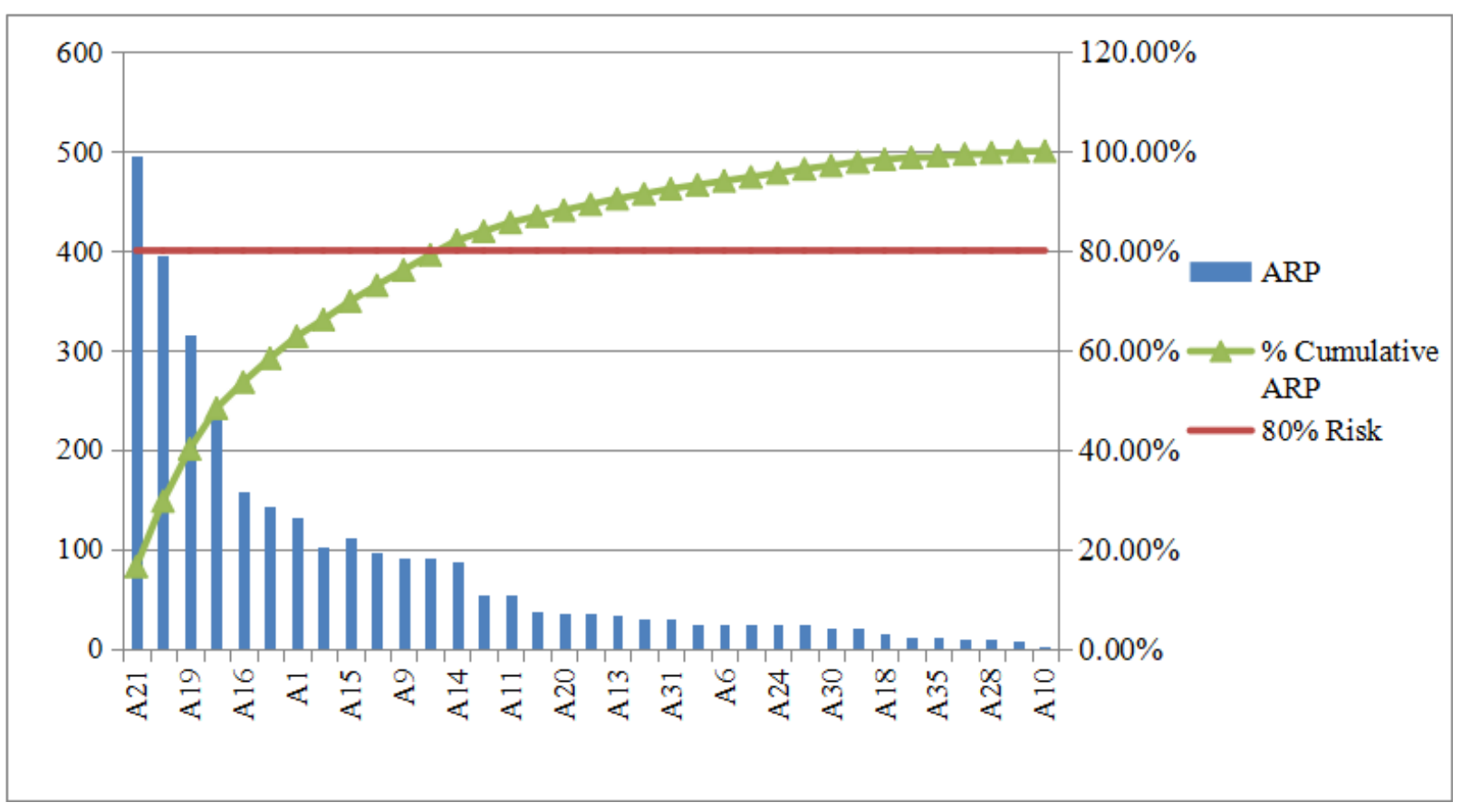

Figure 1. Pareto Diagram of ARP Risk Agent 
Table 5. Risk Agent and Risk Management Strategy

\begin{tabular}{|c|c|c|c|c|c|}
\hline No. & Code & Risk Agent & ARP & Management Strategy & Code \\
\hline \multirow{2}{*}{1.} & \multirow{2}{*}{$\mathrm{A} 21$} & \multirow{2}{*}{$\begin{array}{l}\text { Checking the quality of } \\
\text { raw materials that are not } \\
\text { accurate }\end{array}$} & \multirow{2}{*}{495} & $\begin{array}{l}\text { Apply SOP to determine the } \\
\text { quality of raw materials }\end{array}$ & PA1 \\
\hline & & & & $\begin{array}{l}\text { Forming part of the quality } \\
\text { control of raw materials }\end{array}$ & PA2 \\
\hline \multirow{3}{*}{2.} & \multirow{3}{*}{ A7 } & \multirow{3}{*}{$\begin{array}{l}\text { Delays in procuring raw } \\
\text { materials }\end{array}$} & \multirow{3}{*}{395} & Strategy stock & PA3 \\
\hline & & & & Flexible supply base & PA4 \\
\hline & & & & Coordination & PA5 \\
\hline \multirow{3}{*}{3.} & \multirow{3}{*}{ A19 } & \multirow{3}{*}{ Depending on one supplier } & \multirow{3}{*}{315} & Strategy stock & PA3 \\
\hline & & & & Flexible supply base & PA4 \\
\hline & & & & Coordination & PA5 \\
\hline \multirow{2}{*}{4.} & \multirow{2}{*}{ A12 } & \multirow{2}{*}{$\begin{array}{l}\text { The occurrence of trouble / } \\
\text { damage to the engine }\end{array}$} & \multirow{2}{*}{246} & $\begin{array}{l}\text { Engine maintenance } \\
\text { periodically }\end{array}$ & PA6 \\
\hline & & & & $\begin{array}{l}\text { Provide sufficient spare parts } \\
\text { or engine components }\end{array}$ & PA7 \\
\hline \multirow{4}{*}{5.} & \multirow{4}{*}{ A16 } & \multirow{4}{*}{ Shut down production } & \multirow{4}{*}{158} & $\begin{array}{l}\text { Engine maintenance } \\
\text { periodically }\end{array}$ & PA6 \\
\hline & & & & $\begin{array}{l}\text { Provide sufficient spare parts } \\
\text { or engine components }\end{array}$ & PA7 \\
\hline & & & & $\begin{array}{l}\text { Provides power generator for } \\
\text { backup }\end{array}$ & PA 8 \\
\hline & & & & Coordination & PA5 \\
\hline \multirow{3}{*}{6.} & \multirow{3}{*}{ A17 } & \multirow{3}{*}{$\begin{array}{l}\text { Demand for sudden } \\
\text { purchase of raw materials. }\end{array}$} & \multirow{3}{*}{144} & Strategy stock & PA3 \\
\hline & & & & Flexible supply base & PA4 \\
\hline & & & & Coordination & PA5 \\
\hline \multirow[b]{2}{*}{7.} & \multirow[b]{2}{*}{ A1 } & \multirow{2}{*}{$\begin{array}{l}\text { Significant increase in } \\
\text { demand for organic } \\
\text { fertilizer. }\end{array}$} & \multirow[b]{2}{*}{132} & Strategy stock & PA3 \\
\hline & & & & Coordination & PA5 \\
\hline \multirow{2}{*}{8.} & \multirow{2}{*}{ A4 } & \multirow{2}{*}{$\begin{array}{l}\text { Sudden demand of organic } \\
\text { fertilizer }\end{array}$} & \multirow{2}{*}{102} & Strategy stock & PA3 \\
\hline & & & & Coordination & PA5 \\
\hline & & & & Strategy stock & PA3 \\
\hline 9. & A 15 & Coal supply is disrupted & 111 & Flexible supply base & PA4 \\
\hline & & & & Coordination & PA5 \\
\hline 10. & A 32 & $\begin{array}{l}\text { Lack coordination in } \\
\text { shipping }\end{array}$ & 96 & Coordination & PA5 \\
\hline 11. & A9 & $\begin{array}{l}\text { Poor coordination in the } \\
\text { warehouse of raw material } \\
\text { storage }\end{array}$ & 92 & Coordination & PA5 \\
\hline 12. & A34 & $\begin{array}{l}\text { Disturbance during the } \\
\text { product delivery }\end{array}$ & 92 & Flexible transportation & PA9 \\
\hline
\end{tabular}

Sources: primary data is processed (2018) 
Table 6. The Rank of Supply Chain Risk Management Strategy

\begin{tabular}{clcccc}
\hline Code & \multicolumn{1}{c}{ Strategy } & TEk & DEk & ETD & Rank \\
\hline PA5 & Coordination & 11829 & 3 & 3943 & 1 \\
\hline PA3 & Strategy stock & 6279 & 3 & 2093 & 2 \\
\hline PA4 & Flexible supply base & 8685 & 5 & 1737 & 3 \\
\hline PA1 & $\begin{array}{l}\text { Apply SOP to determine the } \\
\text { quality of raw materials }\end{array}$ & 4455 & 3 & 1485 & 4 \\
\hline PA6 & $\begin{array}{l}\text { Engine maintenance } \\
\text { periodically }\end{array}$ & 3636 & 3 & 1212 & 5 \\
\hline PA7 & $\begin{array}{l}\text { Provide sufficient spare parts or } \\
\text { engine components }\end{array}$ & 3636 & 3 & 1212 & 6 \\
\hline PA2 & $\begin{array}{l}\text { Forming part of the quality } \\
\text { control of raw materials }\end{array}$ & 1485 & 3 & 495 & 7 \\
\hline PA8 & $\begin{array}{l}\text { Provides power generator for } \\
\text { backup }\end{array}$ & 474 & 4 & 118.5 & 8 \\
\hline PA9 & Flexible transportation & 276 & 4 & 69 & 9 \\
\hline
\end{tabular}

Source: primary data is processed (2018)

the order of priority ranking of recommendations for risk management strategies that have been designed, namely: 1) coordination, 2) strategy stock, 3) flexible supply base, 4) apply SOP to determine the quality of raw materials, 5) maintenance of the machine periodically, 6) provide spare parts or sufficient engine components, 7) establish QC parts of raw material, 8) provide power plants / generators for backup, 9) flexible transportation.

\section{CONCLUSION}

There were 23 risk events and 35 risk agents identified at all stages of the process of organic fertilizer supply chain activities at PT MBA using the SCOR model which consists of five business processes (plan, source, create, send and return). Risk events identified in supply chain activities PT. MBA was on 5 risk activity plans. In source activities there were 3 risk events. On make activities, there were 6 risky events. In deliver activities there were 6 risk events. In the return activity there were 2 risk events. Meanwhile, 12 risk agents that were a priority and need to design risk management strategies, as follow, 1) checking the quality of raw materials that are not accurate, 2) delays in procuring raw materials, 3) depending on one supplier, 4) occurrence of trouble / damage to the engine, 5) shut down production, 6) demand for sudden purchase of raw materials, 7) significant increase in demand for organic fertilizer, 8) sudden demand for products / organic fertilizers, 9) supply of coal is disrupted, 10) lack of coordination in shipping parts, 11) lack of coordination in the warehouse storing raw materials, 12) disturbance during the product delivery. However, the implementation of risk management strategies in supply chain activities was based on the highest to lowest ETD values sequentially including coordination, strategy stock, flexible supply base, implementing SOP to determine the quality of raw materials, periodically maintaining machinery, providing spare parts or sufficient engine components, forming the raw material of QC section, provides electricity generator sets for reserves and flexible transportation. 


\section{REFERENCES}

Anatan, L., and Ellitan, L. 2008. Supply Chain Management Teori dan Aplikasi. Bandung: CV. Alfabeta.

Anwar, S. N. 2011. Manajemen rantai pasokan (supply chain management): konsep dan hakikat. Jurnal Dinamika Informatika 3(2): 1-7.

Astutik, W. D., Santoso, P. B., and Sumantri, Y. 2010. Strategi penanganan risiko pada rantai pasok pupuk organik menggunakan metode fuzzy analytical hierarchy process (FAHP) (Studi kasus di PT Tiara Kurnia, Malang). Jurnal Rekayasa dan Manajemen Sistem Industri 3(3): 558-567.

Blackhurst, J., and Handfield, R. B. 2005. An empirically derived agenda of critical research issues for managing supplychain disruptions. International Journal of Production research 43(19): 4067-4081.

https://doi.org/10.1080/002075405001 51549

Citraresmi, A. D. P. 2017. Identifikasi dan pengukuran risiko rantai pasok produk beras organik (Studi kasus pada PT" X ", Kota Batu). Saintek 2(3): 237248.

Geraldin, H. L., Pujawan, I. N., and Santhi Dewi, D. 2007. Manajemen risiko dan aksi mitigasi untuk menciptakan rantai pasok yang robust. Jurnal Teknologi dan Rekayasa Teknik Sipil: 53-64.

Handayani, D. I. 2016. A review: potensi risiko pada supply chain risk management. Spektrum Industri 14(2009): 1-108.

Immawan, T., and Putri, D. K. 2018. House of risk approach for assessing supply chain risk management strategies: A case study in Crumb Rubber Company Ltd. The $2^{\text {nd }}$ International Conference on Engineering and Technology for Sustainable Development: 1-4. https:// doi.org/10.1051/matecconf/201815401 097

Juttner, U., Peck, H., and Christopher, M. 2003. Supply chain risk management: outlining an agenda for future research. International Journal of Logistics 6(4): 197-210. DOI: 10.1080/13675560310001627016

Kersten, W., Hohrath, P., and Böger, M. 2007. An empirical approach to supply chain risk management: development of a strategic framework. Proceeding POMS Conference 2007: 1-20. Retrieved from http://pomsmeetings.org/ConfProceedi ngs/007/CDProgram/Topics/full_lengt h_papers_files/007-0507.pdf

Kristanto, B., and Hariastuti, N. L. P. 2014. Aplikasi model house of risk (HOR) untuk mitigasi risiko pada supply chain bahan baku kulit. Jurnal Ilmiah Teknik Industri 13(2): 1-10.

Luthfi, A., and Irawan, H. 2012. Analisis risiko rantai pasok dengan model house of risk (HOR) (Studi kasus pada PT. XXX). Jurnal Manajemen Indonesia 12(1): 1-11.

Nurlela, and Suprapto, H. 2014. Identifikasi dan analisis manajemen risiko pada proyek pembangunan infrastruktur bangunan gedung bertingkat. Jurnal Desain Konstruksi 13(2): 114-124. https://doi.org/10.1111/j.14609568.2006.04812.x

Pujawan, I. N. 2005. Supply Chain Management. (I. K. Gunarta, Ed.). Surabaya: Guna Widya.

Pujawan, I. N., and Geraldin, L. H. 2009. House of risk: a model for proactive supply chain risk management. Business Process Management Journal 15(6): 953-967. https://doi.org/10.1108/146371509110 03801

Punniyamoorthy, M., Thamaraiselvan, N., and Manikandan, L. 2013. Assessment of 
supply chain risk: scale development and validation. Benchmarking: An International Journal 20(1): 79-105. https://doi.org/10.1108/146357713112 99506

Suharjito, Marimin, Machfud, Haryanto, B., and Sukardi. 2010. Identifikasi dan evaluasi risiko manajemen rantai pasok komoditas jagung dengan pendekatan logika fuzzy. Jurnal Manajemen dan Organisasi 1(2): 118134.

Tampubolon, F., Bahaudin, A., and Ferdinant, P. F. 2013. Pengelolaan risiko supply chain dengan metode house of risk. Jurnal Teknik Industri 1(3): 222-226.

Tang, O., and Nurmaya Musa, S. 2011. Identifying risk issues and research advancements in supply chain risk management. International Journal of Production Economics 133(1): 25-34. https://doi.org/10.1016/j.ijpe.2010.06. 013

Ulfah, M., and Syamsul, M. 2016. Analisis dan perbaikan manjemen risiko rantai pasok gula rafinasi dengan pendekatan house of risk. Jurnal Teknologi Industri Pertanian 26(1): 87-103.

Ummi, N., Gunawan, A., and Ridwan, M. 2017. Identifikasi risiko pembuatan kue gipang sebagai makanan tradisional khas banten dengan metode house of risk (HOR). Industrial Services 3(1): 342-350. 